\title{
The First Steps in Examining of Carbon Absorption and Nutrient Salt Filtering Capability of Rhodomelaceae Laurencia Papillosa Seaweed over Some Typical Island Communes in Vietnam Coastal Area
}

\author{
Le Xuan $\mathrm{Sinh}^{1}$, Tran Van Phuong ${ }^{2} \&$ Le Van Nam ${ }^{1}$ \\ ${ }^{1}$ Institute of Marine Environment and Resources (VAST), Hai Phong, Viet Nam \\ ${ }^{2}$ Natural Resourse and Environment Department, Hai Phong, Viet Nam \\ Correspondence: Le Xuan Sinh, Institute of Marine Environment and Resources (VAST), No 246, Da nang street, \\ Hai Phong city, Viet Nam. Tel: +84-972-366-858. E-mail: sinhlx@gmail.com
}

Received: August 23, 2019

Accepted: September 25, $2019 \quad$ Online Published: October 12, 2019

doi:10.5539/enrr.v9n4p1

URL: https://doi.org/10.5539/enrr.v9n4p1

\begin{abstract}
Viet Hai is a commune in Cat Hai district, Hai Phong City. The commune is located in the East of Cat Ba island which is the third largest island in Vietnam. Nhon Chau is also an island commune which is located in Quy Nhon city, Binh Dinh province. Nam Du commune is one of four island communes of Kien Hai district, Kien Giang province, and located at 120 kilometers away from the Rach Gia city. The results showed that the averaged values of nutrients absorbed by Rhodomelaceae Laurencia Papillosa in 12 hours were $1.39 \mu \mathrm{g} / \mathrm{l} / \mathrm{day}\left(\mathrm{N}_{-} \mathrm{NO}_{2}{ }^{-}\right)$; $11.74 \mu \mathrm{g} / \mathrm{l} /$ day $\left(\mathrm{N}_{-} \mathrm{NO}_{3}{ }^{-}\right) ; 24.08 \mu \mathrm{g} / \mathrm{l} /$ day $\left(\mathrm{N}-\mathrm{NH}_{4}{ }^{+}\right)$; and $7.83 \mu \mathrm{g} / \mathrm{l} /$ day $\left(\mathrm{P}_{-} \mathrm{PO}_{4}{ }^{3-}\right)$ in Viet Hai commune. In Nhon Chau island commune, the averaged values of nutrients absorbed in 12 hours were $1.25 \mu \mathrm{g} / \mathrm{l} / \mathrm{day}\left(\mathrm{N}_{-} \mathrm{NO}_{2}{ }^{-}\right)$; $7.44 \mu \mathrm{g} / \mathrm{l} /$ day $\left({\mathrm{N}-\mathrm{NO}_{3}}^{-}\right) ; 11.81 \mu \mathrm{g} / \mathrm{l} /$ day $\left(\mathrm{N}-\mathrm{NH}_{4}{ }^{+}\right) ; 23.53 \mu \mathrm{g} / \mathrm{l} /$ day $\left(\mathrm{P}_{-} \mathrm{PO}_{4}{ }^{3-}\right)$, respectively. In $\mathrm{Nam} \mathrm{Du}$ island commune, the nutrients absorbed in 12 hours reached the values of $23.4 \mu \mathrm{g} / \mathrm{l} /$ day $\left(\mathrm{N}-\mathrm{NO}_{2}{ }^{-}\right) ; 15.3 \mu \mathrm{g} / \mathrm{l} / \mathrm{day}\left(\mathrm{N}-\mathrm{NO}_{3}{ }^{-}\right)$; $101.65 \mu \mathrm{g} / \mathrm{l} /$ day $\left(\mathrm{N}-\mathrm{NH}_{4}{ }^{+}\right) ; 30.32 \mu \mathrm{g} / \mathrm{l} /$ day $\left(\mathrm{P}_{-} \mathrm{PO}_{4}{ }^{3-}\right)$, respectively. The average values of carbon absorbed by seaweed biomass in Viet Hai, Nhon Chau, and Nam Du communes were $30.27 \mathrm{mgC} / \mathrm{m}^{2} / \mathrm{h}, 31.31 \mathrm{mgC} / \mathrm{m}^{2} / \mathrm{h}$, $33.00 \mathrm{mgC} / \mathrm{m}^{2} / \mathrm{h}$, respectively.
\end{abstract}

Keywords: Rhodomelaceae Laurncia Papillosa, Viet Nam Coastal Area, Nutrient Filtering Value, Carbon Absorbed

\section{Introduction}

\subsection{Introduce the Problem}

Located in Cat Hai district, Hai Phong city, Vietnam, Viet Hai island commune shares the borders with Gia Luan and Tran Chau commune to the West, Cat Ba town to the South and lies in the East of Cat Ba Island, which is the third largest island in Vietnam. Viet Hai manages 1.41 out of 86 square kilometers of total land area with 88 households counting for 270 people (People Committee of Viet Hai commune, 2018).

Nhon Chau island commune, also known as $\mathrm{Cu}$ Lao Xanh, belongs to Quy Nhon city, Binh Dinh province. The commune covers an area stretching from $109^{\circ} 23^{\prime} 01^{\prime}$ ' $\mathrm{E}$ to $109^{\circ} 24^{\prime} 33^{\prime}$ ' $\mathrm{E}$ and $13^{\circ} 36^{\prime} 11^{\prime}{ }^{\prime} \mathrm{N}$ to $13^{\circ} 38^{\prime} 00^{\prime}$ ' $\mathrm{N}$. It is about 13 kilometers away from the Southwest of Xuan Hoa commune, Song Cau district, Phu Yen province and 24 kilometers away from the Northwest of Quy Nhon province. Nhon Chau has a total area of 3.62 square kilometers with 15 kilometers boundary on land.

Nam Du commune, one of four island communes in Rach Gia city, is located at 120 kilometers away from the city and covers a total area of 190 hectares. Nam Du commune consists of 10 islands including two populated islands with three hamlets. One of the two islands is Hon Ngang, which includes An Phu and An Binh hamlets and covers an area of 59.5 hectares. The other is Hon Mau covering 58.5 hectares with Hon Mau hamlet. This commune comprises 3.611 peoples, the majority of its population are concentrated in Hon Ngang. 


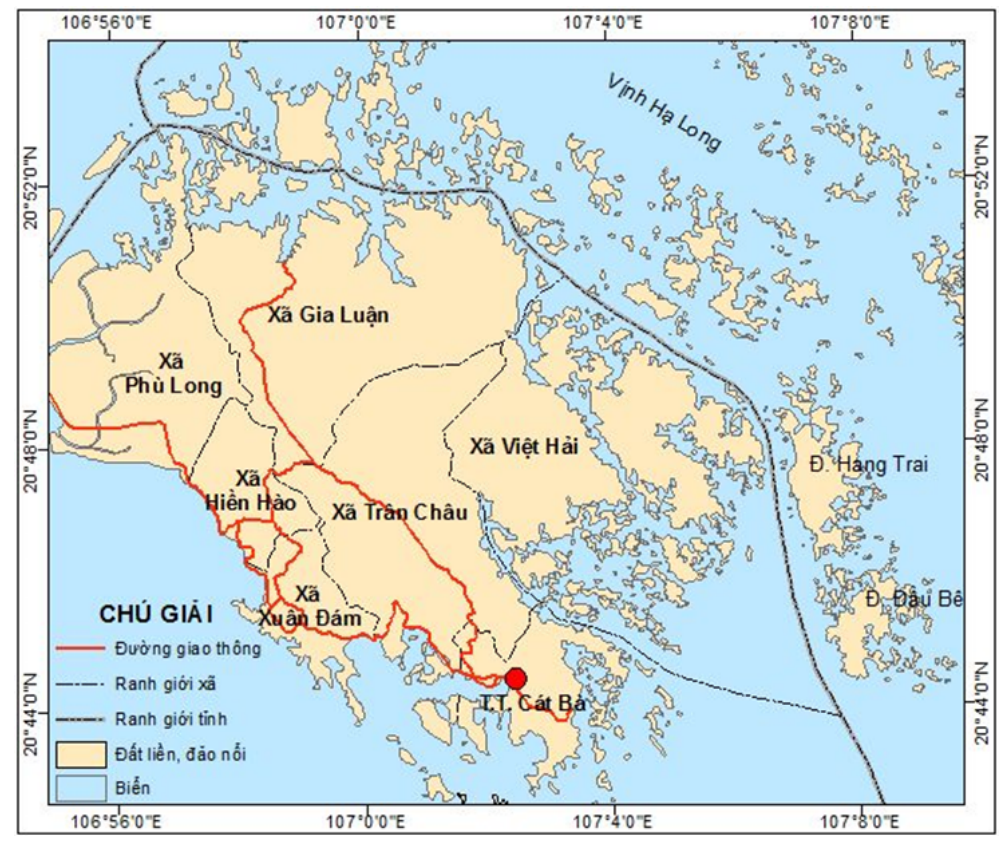

Figure 1. Viet Hai island commune, Cat Hai district in Hai Phong city

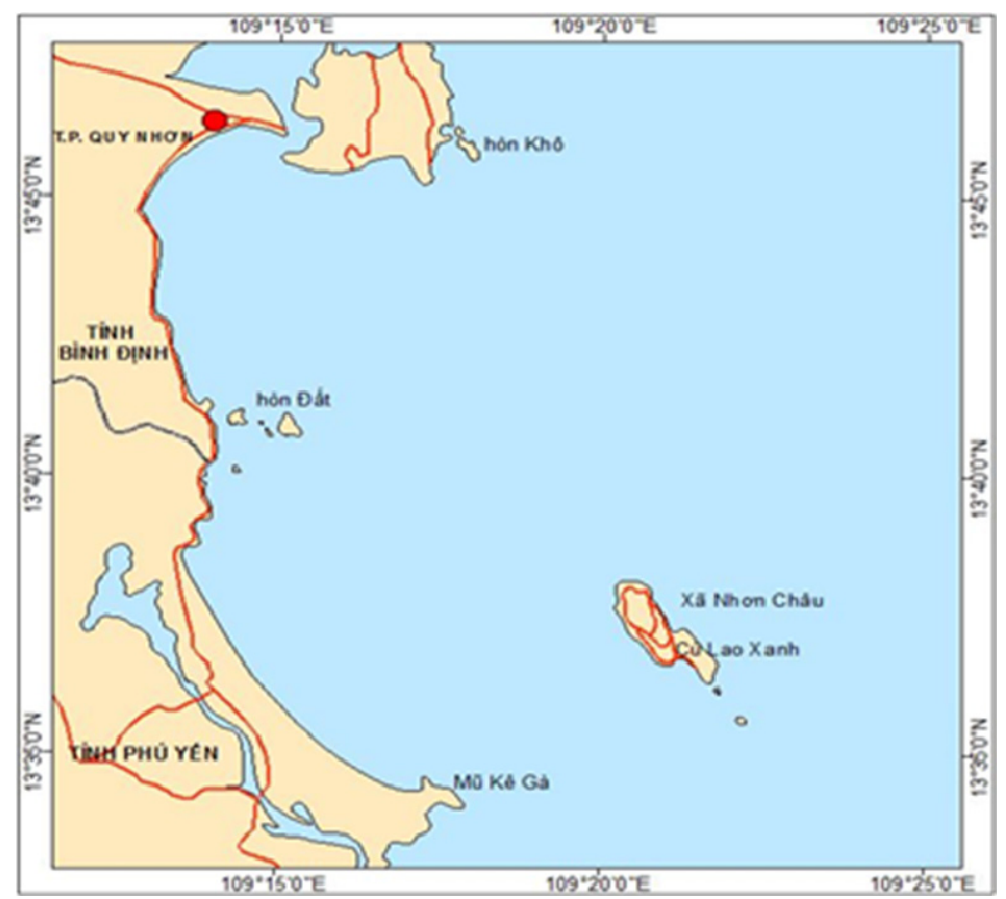

Figure 2. Nhon Chau island commune (Cu Lao Xanh), Quy Nhon, Binh Đinh 


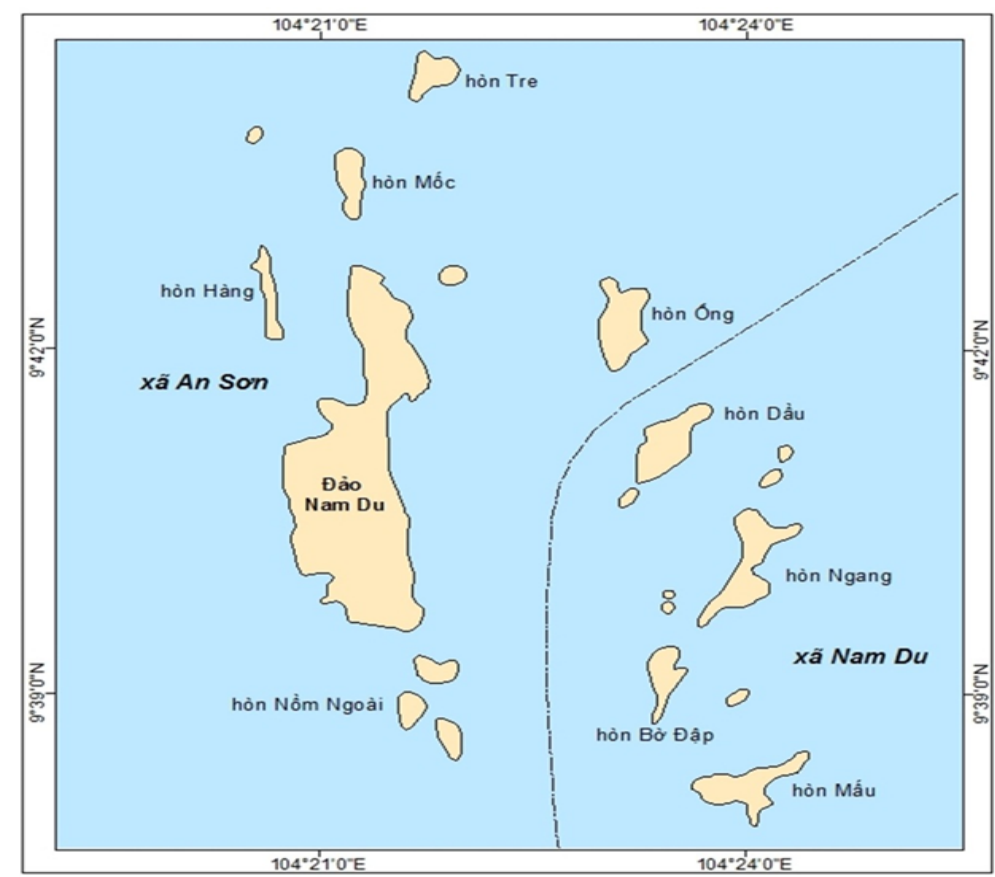

Figure 3. Nam Du island commune, Kien Hai district, Kien Giang province

In addition to the terrestrial ecosystems, the ocean has been known by its Carbon dioxide absorption capacity, which can take up 40 percent of Carbon dioxide $\left(\mathrm{CO}_{2}\right)$ emissions that come from human activities (Smith, 1981). Marine plants, including small size plants (microphyta) and large-sized plants (macrophyta), considerately contribute to the process of absorbing dissolved $\mathrm{CO}_{2}$ through photosynthesis. Recently, many research papers on primary production have been conducted. $\mathrm{CO}_{2}$ fixation and nutrient uptake capacity of marine plants was published by Doan Bo (2009). However, in Vietnam, majority of the studies are conducted with plankton while the large plants such as seaweed and seagrass, which play an important role in carbon fixation and nutrient uptake are of little interest (Trang, Thành, \& Lựu, 2012).

\section{Method}

\subsection{Experimental Method}

Photosynthesis experiments were conducted in Viet Hai, Nhon Chau, and Nam Du communes on March, 2018 based on the methodology provided by Rosenberg et al. (1995). The method is summarized as follows: Rhodomelaceae Laurencia Papillosa seaweed was manually collected at the intertidal zone at a depth of 1 - 2 metres above the sea level. All of the selected samples were the same size and in stage of development.

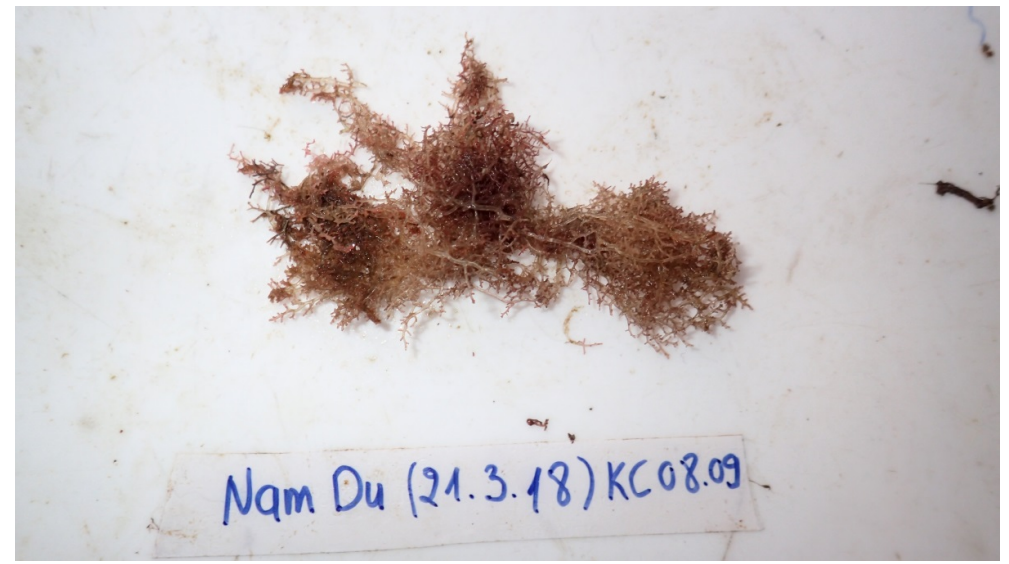

Figure 4. A sample of Rhodomelaceae Laurencia papillosa seaweed (Source: our research, 2018) 
Before conducting the experiments, all of the samples were washed away from the impurities on the surface and stored in seawater tanks placed at experimental zone. The cleaned samples were weighed and divided into samples with the same volume $(10 \mathrm{~g})$ and put into a clear plastic container containing 2 liters of seawater filtered with plankton filter net $(20 \mu \mathrm{m}$ mesh size) to be ready for performing a white and black bottle experiment (Figure 1). The experiment was simultaneously arranged with a control sample consisting of white and black bottles containing filtered seawater only. The bottles were removed from the air by immersing them in a full pot of water and sealed. Those white and black bottles were then fastened and anchored near the sea bed at a depth of 1.5 metres above the sea level. Each experiment was conducted with 3 replication samples and 12-hour experiment time. Seawater parameters including temperature, $\mathrm{DO}, \mathrm{pH}$ and nutrition $\left(\mathrm{N}-\mathrm{NO}_{3}{ }^{-} \mathrm{N}-\mathrm{NH}_{4}{ }^{+}, \mathrm{P}_{-} \mathrm{PO}_{4}{ }^{3-}\right.$ and $\left.\mathrm{N}_{-} \mathrm{NO}_{2}{ }^{-}\right)$were measured before sealing and after completing the experiment to determine the concentration difference of those parameters. After conducting experiments, all of the samples were labeled and dried at a temperature of $600^{\circ} \mathrm{C}$ until the volume remained constant.

Experimental time: the weather at the time of implementing the experiment (on March, 2018) was sunny. Therefore, photosynthesis experiment was conducted from 6am to $6 \mathrm{pm}$, and light intensity was measured by a portable light intensity meter.

Dissolved Oxygen concentration was measured by the YSI 55 meter (USA), the $\mathrm{O}_{2}$ concentration in the samples was detected by Winkle method. PH was measured by Mi105 handheld device (Romania), and the content of nutrient salts was examined by standard colorimetric method using DR / 3900 HACH spectrometer, USA.

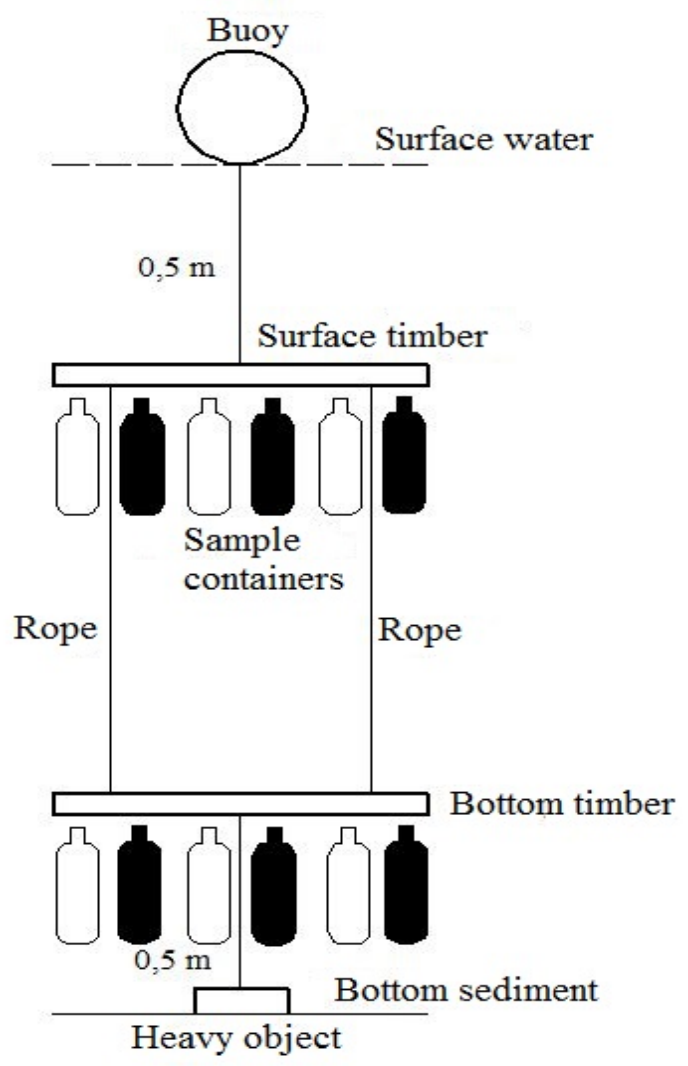

Figure 5. Diagram of field photosynthesis experiment

Oxygen concentration produced by Rhodomelaceae Laurencia papillosa was first determined based on the difference in dissolved oxygen concentration of photosynthesis and respiration process. The NPP is considered as the difference between Gross Primary Production (GPP) and the oxygen consumption during respiration (R). These parameters were calculated as follows:

$$
\begin{gathered}
\mathrm{NPP}=\mathrm{GPP}-\mathrm{R} \\
\mathrm{GPP}=\mathrm{N}_{1}-\mathrm{N}_{0} \\
\mathrm{R}=\mathrm{N}_{0}-\mathrm{N}_{2}
\end{gathered}
$$


While:

NPP: Net Primary Production; GPP: Gross Primary Production; R: Oxygen consumption during respiration; $\mathrm{N}_{0}$ : Initial dissolved oxygen concentration; $\mathrm{N}_{1}$ : dissolved oxygen concentration in while bottle; $\mathrm{N}_{2}$ : dissolved oxygen concentration in black bottle.

The amount of $\mathrm{CO}_{2}$ absorbed during photosynthesis was calculated based on the following equation:

$$
6 \mathrm{CO}_{2}+6 \mathrm{H}_{2} \mathrm{O}=\mathrm{C}_{6} \mathrm{H}_{12} \mathrm{O}_{6}+6 \mathrm{O}_{2}+\Delta \mathrm{H}
$$

Calculating the content of fixed (absorbed) $\mathrm{C}(\mathrm{mgC} / \mathrm{g}$ fresh Rhodomelaceae Laurencia papillosa) from the dissolved oxygen concentration using the conversion formula as below:

$$
m g C=m g D O * \frac{12}{32 . P Q} \text { [Hoffman, W. E., \& Dawes, C. J., 1980] }
$$

While, 12 is the atomic weight of Carbon; 32 is the atomic weight of $\mathrm{O}_{2}$; $\mathrm{PQ}$ is the ratio between the volume of produced oxygen and the volume of carbon absorbed during respiration process.

The amount of $\mathrm{C}$ was then calculated for the study region following equation as below:

$$
\mathrm{C} \text { absorbed }=\mathrm{V} * \mathrm{~B} * \mathrm{PQ} * \mathrm{C}(\text { El Haikali, 2004) }
$$

While:

V: Total area of Rhodomelaceae Laurencia papillosa

B: The biomass of Rhodomelaceae Laurencia papillosa $\left(\mathrm{kg} / \mathrm{m}^{2}\right)$;

$\mathrm{C}$ : The amount of $\mathrm{C}(\mathrm{mgC} / \mathrm{kg})$.

The amount of mineral nutrient absorbed by Rhodomelaceae Laurencia papillosa during photosynthesis process was determined as follows:

$$
\mathrm{M}_{\text {photosynthesis }}=\mathrm{M}_{\text {white bottle }}-\mathrm{M}_{\text {black bottle }}
$$

While:

Mphotosynthesis: The consumed amount of mineral nutrient during photosysthesis $(\mu \mathrm{g} / 1)$;

Mblack bottle: The amount of mineral nutrient in black bottle $(\mu \mathrm{g} / \mathrm{l})$;

Mwhite bottle: The amount of mineral nutrient in white bottle $(\mu \mathrm{g} / 1)$.

The results of the study were calculated into the average value using Microsoft Excel 2010.

\subsection{Analysis Method}

The concentration of some nutrient salts such as $\mathrm{N}_{-} \mathrm{NO}_{3}{ }^{-}, \mathrm{N}-\mathrm{NH}_{4}{ }^{+}, \mathrm{P}_{-} \mathrm{PO}_{4}{ }^{3-}$ and $\mathrm{N}-\mathrm{NO}_{2}{ }^{-}$in seawater was determined by the methods detailed in Table 1 .

Table 1. Methods of determining $\mathrm{N}_{-} \mathrm{NO}_{3}{ }^{-}, \mathrm{N}-\mathrm{NH}_{4}{ }^{+}, \mathrm{P}_{-} \mathrm{PO}_{4}{ }^{3-}$ and $\mathrm{N}-\mathrm{NO}_{2}{ }^{-}$in seawater

\begin{tabular}{ll}
\hline Parameter & Method \\
\hline $\mathrm{N}_{-} \mathrm{NH}_{4}{ }^{+}$ & TCVN 5988:1995 (ISO 5664: 1984) \\
$\mathrm{P}^{-\mathrm{PO}_{4}}{ }^{3-}$ & TCVN 6202:2008 (ISO 6878:2004) \\
$\mathrm{N}^{-} \mathrm{NO}_{3}{ }^{-}$ & TCVN 6180:1996 (ISO 7890-3:1988) \\
$\mathrm{N}_{-}-\mathrm{NO}_{2}^{-}$ & TCVN 6178:1996 (ISO 6777: 1984) \\
\hline
\end{tabular}

\section{Results}

\subsection{Nutrient Filtering Value}

The results showed that the seaweed "Rhodomelaceae Laurencia papillosa" consumed a large amount of nitrogen and phosphorus nutrient salts in the water through photosynthesis process (Table 2). 
Table 2. The nutrient uptake capacity of Rhodomelaceae Laurencia papillosa observed from photosynthesis experiments in three island communes

\begin{tabular}{|c|c|c|c|c|c|}
\hline Experimental areas (12h) & Contents & $\mathrm{N}-\mathrm{NO}_{2}^{-}(\mathrm{n}=3)$ & $\mathrm{N}-\mathrm{NO}_{3}{ }^{-}(\mathrm{n}=3)$ & $\mathrm{N}-\mathrm{NH}_{4}{ }^{+}(\mathrm{n}=3)$ & $\mathrm{P}_{-} \mathrm{PO}_{4}{ }^{3-}(\mathrm{n}=3)$ \\
\hline \multirow{3}{*}{ Viet Hai island commune } & Bright phase (A) & $32.14 \pm 2.12$ & $55.64 \pm 3.06$ & $79.23 \pm 4.12$ & $30.21 \pm 1.09$ \\
\hline & Dark phase (B) & $30.75 \pm 1.11$ & $43.9 \pm 3.01$ & $55.15 \pm 3.11$ & $22.38 \pm 1.15$ \\
\hline & Absorption $=$ A-B & 1.39 & 11.74 & 24.08 & 7.83 \\
\hline \multirow{3}{*}{ Nhon Chau island commune } & Bright phase (A) & $6.54 \pm 0.56$ & $62.68 \pm 4.11$ & $52.26 \pm 3.45$ & $77.57 \pm 4.09$ \\
\hline & Dark phase (B) & $5.29 \pm 0.34$ & $55.24 \pm 3.92$ & $40.45 \pm 2.67$ & $54.04 \pm 3.89$ \\
\hline & Absorption $=\mathbf{A}-\mathbf{B}$ & 1.25 & 7.44 & 11.81 & 23.53 \\
\hline \multirow{3}{*}{ Nam Du island commune } & Bright phase (A) & $74.8 \pm 4.16$ & $75.34 \pm 3.22$ & $211.82 \pm 5.23$ & $105.5 \pm 4.15$ \\
\hline & Dark phase (B) & $51.4 \pm 3.09$ & $60.04 \pm 4.01$ & $110.17 \pm 4.13$ & $75.18 \pm 3.09$ \\
\hline & Absorption $=\mathbf{A}-\mathbf{B}$ & 23.4 & 15.3 & 101.65 & 30.32 \\
\hline
\end{tabular}

Source: Our research in three communes.

From the research result on the Table 2, the average values of nutrients absorbed in 12 hours per day of Rhodomelaceae Laurencia papillosa in Viet Hai island commune were $1.39 \mu \mathrm{g} / \mathrm{l} / \mathrm{day}\left(\mathrm{N}^{-N_{2}}{ }^{-}\right) ; 11.74 \mu \mathrm{g} / \mathrm{l} / \mathrm{day}$ $\left(\mathrm{N}-\mathrm{NO}_{3}{ }^{-}\right) ; 2408 \mu \mathrm{g} / \mathrm{l} / \mathrm{day}\left(\mathrm{N}-\mathrm{NH}_{4}{ }^{+}\right) ; 7.83 \mu \mathrm{g} / \mathrm{l} /$ day $\left(\mathrm{P}^{-} \mathrm{PO}_{4}{ }^{3-}\right)$ respectively. Hence, the daily nutrient uptake capacity of the marine microbial communities in Viet Hai was observed in low value. On the other hand, the values of nutrients absorbed of Rhodomelaceae Laurencia papillosa in 12 hours per day in Nhon Chau island commune were respectively $1.25 \mu \mathrm{g} / \mathrm{l} / \mathrm{day}\left(\mathrm{N}_{-} \mathrm{NO}_{2}{ }^{-}\right) ; 7.44 \mu \mathrm{g} / \mathrm{l} /$ day $\left(\mathrm{N}^{-\mathrm{NO}_{3}}{ }^{-}\right) ; 11.81 \mu \mathrm{g} / \mathrm{l} / \mathrm{day} \quad\left(\mathrm{N}^{-\mathrm{NH}_{4}}{ }^{+}\right) ; 23.53 \mu \mathrm{g} / \mathrm{l} / \mathrm{day}$ $\left(\mathrm{P}_{-} \mathrm{PO}_{4}{ }^{3-}\right)$. To the experiment in Nam Du island commune, the research result showed that, the values of nutrients absorbed in 12 hours per day of Rhodomelaceae Laurencia papillosa were: $23.4 \mu \mathrm{g} / \mathrm{l} / \mathrm{day}\left(\mathrm{N}^{-\mathrm{NO}_{2}}{ }^{-}\right) ; 15.3 \mu \mathrm{g} / \mathrm{l} / \mathrm{day}$ $\left(\mathrm{N}-\mathrm{NO}_{3}{ }^{-}\right) ; 101.65 \mu \mathrm{g} / \mathrm{l} /$ day $\left(\mathrm{N}-\mathrm{NH}_{4}{ }^{+}\right) ; 30.32 \mu \mathrm{g} / \mathrm{l} /$ day $\left(\mathrm{P}^{-} \mathrm{PO}_{4}{ }^{3-}\right)$.

The results indicated that nutrient filtering value of Rhodomelaceae Laurencia papillosa observed from photosynthesis experiments in three island communes is shown in Table 3:

Table 3. The nutrient uptake capacity of Rhodomelaceae Laurencia papillosa observed from photosynthesis experiments in three island communes

\begin{tabular}{|c|c|c|c|}
\hline Experimental areas & Nam Du (Kien Giang) & Nhon Chau (Binh Đinh) & Viet Hai (Hai Phong) \\
\hline Nutrient value $\mathrm{N}^{-\mathrm{NO}_{2}}{ }^{-}(\mu \mathrm{g} / \mathrm{l})$ & 23.4 & 1.25 & 1.39 \\
\hline Nutrient value $\mathrm{N}^{-\mathrm{NO}_{3}}{ }^{-}(\mu \mathrm{g} / \mathrm{l})$ & 15.3 & 7.44 & 11.74 \\
\hline Nutrient value $\mathrm{N}-\mathrm{NH}_{4}{ }^{+}(\mu \mathrm{g} / \mathrm{l})$ & 101.6 & 11.81 & 24.08 \\
\hline Nutrient value $\mathrm{P}_{-} \mathrm{PO}_{4}{ }^{3-}(\mu \mathrm{g} / \mathrm{l})$ & 30.32 & 23.53 & 7.83 \\
\hline
\end{tabular}

The research result shows that the nutrient uptake capacity of Rhodomelaceae Laurencia papillosa observed in Nam Du island commune is highest compared to the experimental result of two communes Nhon Chau, Viet Hai. The carbon absorption capacity of seaweed ecosystems in Nam Du is also higher than two other communes.

This can be explained by the water quality of the three areas. Turbidity measured in seawater in Nam Du commune area was 2.08 FTU, while turbid in seawater at the experimental sites in Viet Hai commune (5.60 FTU), Nhon Chau commune (2.28 FTU).

\subsection{Carbon Absorption Value}

Seaweed communities are a component of marine ecosystems and constitute an important component in the subtidal and intertidal ecosystem. Here are the results of experiments to evaluate the carbon absorption capacity of seaweed ecosystems in seawater at research sites (Table 4).

Table 4. The carbon absorption value of seaweed Rhodomelaceae Laurencia papillosa in three island communes

\begin{tabular}{llll}
\hline Research Sites & Nam Du (Kien Giang) & Nhon Chau (Binh Đinh) & Viet Hai (Hai Phong) \\
\hline Carbon absorbed by seaweed biomass $\left(\mathrm{mgC} / \mathrm{m}^{2} / \mathrm{h}\right)$ & 32.93 & 31.31 & 30.27 \\
The distribution of seaweed $\left(\mathrm{kg} / \mathrm{m}^{2}\right)$ & 3.7 & 3.6 & 4.3 \\
\hline
\end{tabular}


The research result showed that, sparse reserve of seaweed in the coastal areas of Viet Hai island commune was very low. The species of seaweed are distribute sparsely. There was an alternating structure between the biological and benthic ecosystems with sand and gravel. The submerged areas were covered by corals and seaweed. The seaweed Rhodomelaceae Laurencia papillosa is collected to do experiment and measure the role of cacbon absorbtion in Viet Hai island commune.

Experimental results assessing the carbon absorption capacity of seaweed ecosystems in the seawater in Viet Hai island commune reached $7.04 \mathrm{mgC} / \mathrm{kg} /$ hour. It was estimated that the average amount of carbon absorbed by seaweed biomass was $30.27 \mathrm{mgC} / \mathrm{m}^{2} / \mathrm{h}$, based on the distribution of seaweed of $4.3 \mathrm{~kg} / \mathrm{m}^{2}$.

The research result on seaweed communities over Cu Lao Xanh, Hon Dat and Hon Kho islands and Thi Nai lagoon (2003-2004) were observed with a total of 71 species of seaweed (Doan Bo, 2009), of which high-iodine and alginic acid - rich species were encouraged to be used as food (Ulvaceae, Porphyra, Hypneaceae. etc), cattle feed and fertilizers (Chlorophyta, Rhodophyta, etc).

For examining the role of Carbon absorbtion of seaweed communities (Rhodomelaceae Laurencia papillosa) distributed in the area of Nhon Chau island commune, the experimental result showed that the carbon absorption capacity of seaweed ecosystems in seawater in Nhon Chau commune was $8.7 \mathrm{mgC} / \mathrm{kg} / \mathrm{hour}$. The average amount of carbon absorbed by seaweed biomass was $31.31 \mathrm{mgC} / \mathrm{m}^{2} / \mathrm{h}$, estimated from the distribution of seaweed of $3.6 \mathrm{~kg} / \mathrm{m}^{2}$.

In order to research and determine the accumulation value of carbon absorption of the typical marine ecosystems including seaweed, seagrass, salt marsh plants in the coastal zone of Nam Du island commune, the authors focused on investigating the carbon absorption capacity of the seaweed communities Rhodomelaceae Laurencia papillosa which are distributed in the intertidal ecosystem of this coastal area.

Distribution of this seaweed species is quite diverse and large coverage at the survey points around Hon Mau, Bo Dam and Hon Dau islands. The carbon absorption capacity of seaweed ecosystems in sea water in Nam Du reached to $8.9 \mathrm{mgC} / \mathrm{kg}$ /hour following the experimental results. The average amount of carbon absorbed by seaweed biomass reached the value of $33 \mathrm{mgC} / \mathrm{m}^{2} / \mathrm{h}$ calculated from distribution of seaweed content of $3.7 \mathrm{~kg} / \mathrm{m}^{2}$.

Besides, the value of carbon absorption is not only based on the limpid of water but also based on the sunlight factor in the study area. Distribution of sunshine hours of three North, Central and Southern regions are different. Number of sunshine hours in Viet Hai area is from $1500 \mathrm{~h}$ to $1700 \mathrm{~h}$ / year, Nhon Chau area (2000h-2200h / year), Nam Du commune (2400h-2500h / year) (Phan, 2012).

It means that the sunshine time is directly proportional to the estimated values of biomass absorbed carbon in each study area. Nam Du Island which is located in the southern region of Vietnam has only two rainy and dry seasons. Its temperature varies from 27 to $35^{\circ} \mathrm{C}$ accounting the highest number of sunny hours in the country, so its absorbed carbon from biomass is $32.93 \mathrm{mgC} / \mathrm{m}^{2} / \mathrm{h}$.

The value of carbon absorbtion by seaweed biomass is higher than that of Nhon Chau and Nam Du island communes, although the distribution of seaweed biomass in Viet Hai commune is lower. Meanwhile, Viet Hai island commune has the highest distribution in the three studied island communes reaching $4.3 \mathrm{~kg} / \mathrm{m}^{2}$, up to 1.16 times but the absorbing value based on seaweed biomass is lower than both rest points, reached $30.27 \mathrm{mgC} / \mathrm{m}^{2} / \mathrm{h}$.

Thus, it can be seen that the same species of Rhodomelaceae Laurencia papillosa are distributed in regions ensured by environmental conditions such as turbidity, the number of sunshine hours that result in different nutrient absorption, different carbon absorption. The differences are explained as in any coastal area the water is more limpid, the light is stronger, the results measured of nutrient absorption and carbonation are also higher. This is significant in protecting seaweed ecosystems - which is considered as forests under the seabed, cleaning the environment, absorbing carbon to combat the increase of carbon content in sea water, even preventing climate change.

\section{Discussion}

In conclusion, the average amount of carbon absorbed by seaweed Rhodomelaceae Laurencia papillosa during 12 hours/day was determined in three study areas for parameters $\mathrm{N}^{-\mathrm{NO}_{2}}{ }^{-}, \mathrm{N}-\mathrm{NO}_{3}{ }^{-}, \mathrm{N}-\mathrm{NH}_{4}{ }^{+}, \mathrm{P}_{-}-\mathrm{PO}_{4}{ }^{3-}$. The research result shows that the nutrient absorption value of the seaweed communities in Nam Du is highest, Nhon Chau is the second and the lowest is Viet Hai.

To carbon absorption, there is a difference in carbon absorption value among three research sites. By the other word, the amount of absorbed carbon in three areas could be measured based on seaweed biomass $\left(\mathrm{mgC} / \mathrm{m}^{2} / \mathrm{h}\right)$ in 
which this amount in Viet Hai Commune is $30.27 \mathrm{mgC} / \mathrm{m}^{2} /$ hour, in Nhon Chau commune: $31.31 \mathrm{mgC} / \mathrm{m}^{2} / \mathrm{h}$ and in Nam Du commune is $32.93 \mathrm{mgC} / \mathrm{m}^{2} / \mathrm{h}$.

Absorption value of seaweed Rhodomelaceae Laurencia papillosa depends heavily on the clarity of seawater, the number of sunny hours. The area in Nam Du has the highest carbon absorption value, then to Nhon Chau commune and Viet Hai is the lowest.

\section{Acknowledgments}

The authors of this study acknowledged the research entitled "Research on developing a model of Green economy for some typical island communes in Viet Nam coastal areas" - Reference no. KC.08.09/16-20 for providing us materials to conduct this study.

\section{Conflict of interests}

The authors declare that there is no conflict of interests regarding the publication of this paper.

\section{References}

Doan Bo. (2009). Distribution characteristics and changes in primary biological productivity in the West Sea of Northern Gulf. Scientific Journal of Hanoi National University, Natural Science and Technology, 1(25), 21-27.

El Haikali, B., Bensoussan, N., Romano, J. C., \& Bousquet, V. (2004). Estimation of photosynthesis and calcification rates of Corallina elongata Ellis and Solander, 1786, by measurements of dissolved oxygen, $\mathrm{pH}$ and total alkalinity. Scientia Marina, 68(1), 45-56.

Hoffman, W. E., \& Dawes, C. J. (1980). Photosynthetic rates and primary production by two Florida benthic red algal species from a salt marsh and a mangrove community. Bulletin of Marine Science, 30(2), 358-364.

People Committee of Viet Hai commune. (2018). Explanation of the general planning for new rural construction of Viet Hai commune - Cat Hai district - Hai Phong City for the period of 2018 - 2020 with orientation to 2020. Planning Report (2018), 1-20.

Phan, T. T., Vu, C. M., \& và Wasielke, A. (2012). Status of wind power development and financing of these projects in Vietnam VN. Retrieved from http://gizenergy.org.vn/media/app/media/Bao\%20cao\%20 nghien\%20cuu/Status_of_wind_power_development_and_financing_of_these_projects_in_Vietnam_VN_0 9042012.pdf

Rosenberg, G., Littler, D. S., Littler, M. M., \& Oliveira, E. C. (1995). Primary production and photosynthetic quotients of seaweeds from Sao Paulo state, Brazil. Botanica Marina, 38(1-6), 369-378.

Smith, S. V. (1981). Marine macrophytes as a global carbon sink, 211(4484), 838-840 \& 34-36.

Trang, C. T. T., Thành, T., \& Lựu, V. T. (2012). Primary productivity of Pha Tam Giang - Cau Hai lagoon area. Collection of Marine Resources and Environment, Episode XVII. Science and Technology Publishing House, 196-204. Hanoi.

\section{Copyrights}

Copyright for this article is retained by the author(s), with first publication rights granted to the journal.

This is an open-access article distributed under the terms and conditions of the Creative Commons Attribution license (http://creativecommons.org/licenses/by/4.0/). 